\title{
Phosphorylase kinase from chicken gizzard Partial purification and characterization
}

\author{
Stathis NIKOLAROPOULOS and Theodore G. SOTIROUDIS \\ Centre of Biological Research, The National Hellenic Research Foundation, Athens
}

(Received April 1/June 13, 1985) - EJB 850345

\begin{abstract}
Phosphorylase kinase was partially purified ( 530 - 970-fold) from chicken gizzard smooth muscle by a procedure involving ammonium sulfate fractionation, chromatography on 8-(6-aminohexyl)adenosine-5'-phosphateSepharose 4B and glycerol density gradient ultracentrifugation. The final and most efficient purification step takes advantage of the relatively high molecular mass of gizzard phosphorylase kinase, which was found to be similar to that of rabbit skeletal muscle enzyme. The gizzard kinase, further purified to near homogeneity by calmodulin-Sepharose 4B affinity chromatography, showed one main protein band of $61 \mathrm{kDa}$, upon dodecyl sulfate acrylamide gel electrophoresis. Four minor protein bands of higher molecular mass were also present but no protein stain was seen at the position of the $\gamma$ subunit. The gizzard phosphorylase kinase showed a high $\mathrm{pH} 6.8 /$ 8.2 activity ratio of 0.53 , it was stimulated by $\mathrm{Ca}^{2+}$, inhibited up to $80 \%$ by EGTA and it was activated about 1.9-fold by calmodulin. The $k_{\mathrm{m}}$ value for ATP was $0.45 \mathrm{mM}$, while the $K_{0.5}$ for rabbit muscle phosphorylase $b$ was extremely low, more than 200 -fold lower than the $K_{\mathrm{m}}$ of nonactivated skeletal muscle phosphorylase kinase for its protein substrate. High concentrations of phosphorylase $b$ were found to be inhibitory. At $10 \mathrm{mg} / \mathrm{ml}$ phosphorylase $b$, the maximum activity of the kinase was inhibited fivefold. No evidence has been obtained indicating autophosphorylation or the existence of active and inactive forms of gizzard phosphorylase kinase. Limited proteolysis of the smooth muscle kinase with trypsin was accompanied by a twofold activation at $\mathrm{pH} 6.8$.
\end{abstract}

Phosphorylase kinase is a regulatory enzyme in the cascade of reactions associated with glycogenolysis. The rabbit skeletal muscle enzyme has been the most intensively studied. This enzyme is a hexadecamer composed of four types of subunits: $\alpha_{4} \beta_{4} \gamma_{4} \delta_{4}$ [1] and exists in active and inactive forms. The active and inactive forms can be distinguished by their $\mathrm{pH} /$ activity profiles. Conversion of the nonactivated to the activated form occurs by protein phosphorylation, which can be catalyzed by a number of protein kinases [2]. In addition, the activity of skeletal muscle phosphorylase kinase is dependent on $\mathrm{Ca}^{2+}$, while different findings suggest that the activation of phosphorylase kinase by $\mathrm{Ca}^{2+}$ represents the mechanism by which glycogenolysis is synchronized with muscle contraction [3]

In the last few years there has been a surge of interest in smooth muscle biochemistry and especially in the regulation of contractile process by protein phosphorylation $[4,5]$. In addition, the regulation of phosphorylase $a$ formation has been examined in intact smooth muscle and in general it has been proposed that increases in phosphorylase $a$ formation are related to increases in contractile activity due to changes in intracellular free $\mathrm{Ca}^{2+}$ concentrations $[6,7]$. The relationship between myosin light chain phosphorylation and phosphorylase $a$ formation has also been examined [8], but for a

Correspondence to T. G. Sotiroudis, Centre of Biological Research, The National Hellenic Research Foundation, 48 Vassileos Constantinou Avenue, Athens 11635, Greece

Abbreviations. SDS, sodium dodecyl sulfate; 5'AMP-Sepharose, 8-(6-aminohexyl)adenosine-5'-phosphate-Sepharose; $\mathrm{PhMeSO}_{2} \mathrm{~F}$, phenylmethylsulfonyl fluoride.

Enzymes. Cyclic-AMP-dependent protein kinase (EC 2.7.1.37); phosphorylase kinase (EC 2.7.1.38); glycogen phosphorylase (EC 2.4.1.1); phosphorylase phosphatase (EC 3.1.3.17). better understanding of the coordination of metabolic and contractile activity in smooth muscle the purification of the enzymes involved in the above regulatory mechanisms is needed.

Since smooth muscle phosphorylase kinase has not been purified or studied to any extent, the purification and characterization of chicken gizzard phosphorylase kinase was undertaken to facilitate understanding of the hormonal control of glycogen metabolism in smooth muscle.

\section{MATERIALS AND METHODS}

\section{Materials}

$\left[\gamma_{-}{ }^{32} \mathrm{P}\right]$ ATP $(3 \mathrm{Ci} / \mathrm{mmol}$ ) was purchased from the Radiochemical Centre, Amersham. Sepharose 4B, 5'AMP-Sepharose $4 \mathrm{~B}$ and phenyl-Sepharose $\mathrm{CL}-4 \mathrm{~B}$ were obtained from Pharmacia. PhMeSO $2 \mathrm{~F}$ and ATP were products of Sigma Chemical Co. and BDH respectively. Glycogen from oyster was purchased from BDH and was freed of AMP as described previously [9]. Flake poly(ethyleneglycol) (Aquacide III) was a product of Calbiochem-Behring Corp. Other chemicals used were of the highest grade commercially available.

\section{Protein preparations}

Crystalline rabbit skeletal muscle phosphorylase $b$ was prepared according to Fischer and Krebs [10], recrystallized four times and treated as described previously [9]. Rabbit skeletal muscle phosphorylase kinase was purified by the method of Cohen [11]. Muscle phosphorylase $a$ was prepared from phosphorylase $b$ by phosphorylation with rabbit muscle phosphorylase kinase [9]. The catalytic subunit of bovine heart 
cyclic-AMP-dependent protein kinase, bovine brain calmodulin and whole troponin were kindly provided by Prof. L. M. G. Heilmeyer, Jr. Calmodulin was also isolated from bovine brain by phenyl-Sepharose affinity chromatography [12]. Casein hydrolyzed and partially dephosphorylated, phosvitin from egg vitellin, histone type II-AS from calf thymus, trypsin twice crystallized and soybean trypsin inhibitor were obtained from Sigma. Protein phosphatase 1 was partially purified from rabbit skeletal muscle as described by Antoniw and Cohen [13].

\section{Phosphorylase kinase assay}

Phosphorylase kinase activity was determined by a modification of the method of Cohen [11], which is based on the measurement of phosphorylase activity. Unless otherwise noted, the incubation mixture contained $50 \mathrm{mM}$ glycerol 2-phosphate, $50 \mathrm{mM}$ Tris $/ \mathrm{HCl}$, pH 6.8 or $8.6,3 \mathrm{mM}$ ATP, $10 \mathrm{mM}$ magnesium acetate, $0.1 \mathrm{mM} \mathrm{CaCl}_{2}$, phosphorylase $b$, $0.5 \mathrm{mg} / \mathrm{ml}$ (for gizzard kinase) or $8 \mathrm{mg} / \mathrm{ml}$ (for skeletal muscle kinase) and the phosphorylase kinase preparation to be assayed in a final volume of $0.15 \mathrm{ml}$. The reaction was started by the addition of a mixed solution of ATP and magnesium acetate. After incubation for $10 \mathrm{~min}$ at $30^{\circ} \mathrm{C}, 0.02 \mathrm{ml}$ of reaction mixture was appropriately diluted in ice-cold $30 \mathrm{mM}$ triethanolamine- $\mathrm{HCl}$ buffer $\mathrm{pH} 6.8$ containing $0.5 \mathrm{mg} / \mathrm{ml}$ bovine serum albumin and $20 \mathrm{mM}$ 2-mercaptoethanol and assayed for phosphorylase $a$ in the direction of glycogen synthesis [9], with $75 \mathrm{mM}$ glucose-1-P. Phosphorylase kinase activity was expressed as the rate that phosphorylase $b$ monomer is converted to phosphorylase $a$ monomer: $1 \mathrm{U}=1 \mu \mathrm{mol}$ converted $/ \mathrm{min}$. The specific activity of phosphorylase $a$ in the absence of AMP was taken was $54 \mathrm{U} / \mathrm{mg}$ [11].

Phosphorylase kinase was alternatively assayed by measuring the incorporation of ${ }^{32} \mathrm{P}$ from $\left[\gamma-{ }^{32} \mathrm{P}\right] \mathrm{ATP}$ into the protein substrate. The incubation mixture was similar to that described by Cohen [14], except that $\left[\gamma_{-}{ }^{32} \mathrm{P}\right]$ ATP was $1 \mathrm{mM}$ and phosphorylase $b 0.5 \mathrm{mg} / \mathrm{ml}$ (for gizzard kinase) or $8 \mathrm{mg} /$ $\mathrm{ml}$ (for skeletal muscle kinase) in a final volume of $0.06 \mathrm{ml}$. When the activity of gizzard phosphorylase kinase was measured against different potential protein substrates, the assay mixture contained $3 \mathrm{mg} / \mathrm{ml}$ of the protein substrate.

\section{Protein determination}

Protein determinations during the purification procedure of gizzard phosphorylase kinase utilized the Coomassie Brilliant Blue G-250 microprotein assay, as described by Bradford [15], using bovine serum albumin as the standard. Protein concentrations of the purified enzymes were determined spectrophotometrically by using the absorption coefficients $\left(A_{1}^{1 \%} \mathrm{~cm}\right)$ at $280 \mathrm{~nm}$ of 12.4 and 13.2 for rabbit muscle phosphorylase kinase [11] and phosphorylase [16] respectively.

\section{SDS gel electrophoresis}

Polyacrylamide gel electrophoresis with $5 \%$ or $7.5 \%$ acrylamide gels in presence of $0.1 \%$ SDS was carried out as described by Cohen [11]. Samples of phosphorylase kinase were precipitated by $15 \%$ trichloroacetic acid and the protein centrifuged down. The pellets were washed extensively with diethyl ether and denatured by boiling with $1 \%$ SDS for $5 \mathrm{~min}$, in the presence of $0.2 \%(\mathrm{v} / \mathrm{v})$ 2-mercaptoethanol. Rabbit muscle phosphorylase kinase was used as standard.

\section{Other procedures}

The activity of phosphorylase phosphatase was measured by the rate of conversion of phosphorylase $a$ to $b$ [17]. The effect of phosphorylase phosphatase on chicken gizzard phosphorylase kinase was tested by incubation of the smooth muscle enzyme $(20 \mu \mathrm{g} / \mathrm{ml})$ with $0.13 \mathrm{mg} / \mathrm{ml}$ of phosphorylase phosphatase in $30 \mathrm{mM}$ Tris/ $\mathrm{HCl}$ buffer $\mathrm{pH} 7.0$ containing $1 \mathrm{mM}$ EDTA, $0.1 \mathrm{mM}$ phenylmethylsulfonyl fluoride and $15 \mathrm{mM}$ 2-mercaptoethanol, for $10 \mathrm{~min}$ at $30^{\circ} \mathrm{C}$, in a final volume of $0.12 \mathrm{ml}$. Aliquots were removed and tested for phosphorylase kinase activity, in the presence of $20 \mathrm{mM} \mathrm{NaF}$, at $\mathrm{pH} 6.8$.

Enzymatic activation of gizzard phosphorylase kinase was examined in principle as described by Chrisman et al. [18] by preincubating phosphorylase kinase with ATP-Mg and the catalytic subunit of cyclic-AMP-dependent protein kinase, followed by measuring the phosphorylase kinase activity as described above. The preincubation mixture contained

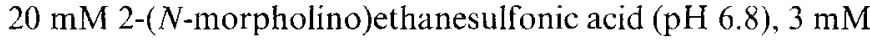
magnesium acetate, $50 \mu \mathrm{M}$ ATP, gizzard phosphorylase kinase $(20 \mu \mathrm{g} / \mathrm{ml})$ and the catalytic subunit of cyclic-AMPdependent protein kinase $(500 \mu \mathrm{g} / \mathrm{ml})$, in a final volume of $0.1 \mathrm{ml}$. The reaction was started by the addition of ATP and at different time intervals, at $30^{\circ} \mathrm{C}$, aliquots were taken and directly added to the phosphorylase kinase assay mixture.

Autophosphorylation of rabbit skeletal muscle and chicken gizzard phosphorylase kinase $(40 \mu \mathrm{g} / \mathrm{ml})$ was carried out at $30^{\circ} \mathrm{C}$ for $2 \mathrm{~h}$ in the presence of $1 \mathrm{mM} \mathrm{CaCl}, 0.6 \mathrm{mM}$ EDTA, $1.6 \mathrm{mM}$ magnesium acetate, $0.5 \mathrm{mM}\left[\gamma_{-}{ }^{32} \mathrm{P}\right] \mathrm{ATP}, 34 \%$ $(\mathrm{v} / \mathrm{v})$ glycerol, $0.06 \mathrm{mM}$ phenylmethylsulfonyl fluoride, $15 \mathrm{mM}$ 2-mercaptoethanol and $20 \mathrm{mM}$ Tris/ $/ \mathrm{HCl}$ buffer $\mathrm{pH} 7.3$ in a final volume of $0.5 \mathrm{ml}$. The reaction was stopped by addition of ice-cold trichloroacetic acid and the samples were prepared for SDS-acrylamide gel electrophoresis $(7.5 \%$ gel) as described previously. The gels were dried onto Whatman No $3 \mathrm{MM}$ paper and autoradiographed on Kodak $\mathrm{X}$-Omat S film with X-ray intensifying screen, for $12 \mathrm{~h}$ (skeletal muscle phosphorylase kinase) or 27 days (gizzard phosphorylase kinase) at $-70^{\circ} \mathrm{C}$

Trypsinolysis of rabbit skeletal muscle and chicken gizzard phosphorylase kinase was carried out by incubating the kinase $(5 \mu \mathrm{g} / \mathrm{ml})$ with trypsin $(2 \mu \mathrm{g} / \mathrm{ml})$ at $30^{\circ} \mathrm{C}$. The incubation mixture also contained $0.6 \mathrm{mM}$ EDTA, $0.06 \mathrm{mM}$ phenylmethylsulfonyl fluoride, $10 \mathrm{mM}$ 2-mercaptoethanol, $40 \%(\mathrm{v} / \mathrm{v})$ glycerol and $20 \mathrm{mM}$ Tris/ $\mathrm{HCl}$ buffer $\mathrm{pH} 7.3$. At various times an aliquot was diluted $1: 10$ in the phosphorylase kinase assay mixture ( $\mathrm{pH}$ 6.8) which contained $21 \mu \mathrm{g} / \mathrm{ml}$ trypsin inhibitor and the enzyme activity was determined as described previously.

Coupling of calmodulin to Sepharose $4 \mathrm{~B}$ was done according to Niggli et al. [19].

\section{RESULTS}

\section{Partial purification of chicken gizzard phosphorylase kinase}

All purification procedures were carried out at $0-4 \mathrm{C}$. The gizzard muscle (three chicken) was homogenized in 2.5 vol. of buffer containing $30 \mathrm{mM}$ Tris/ $\mathrm{HCl}, 1 \mathrm{mM}$ EDTA, $0.1 \mathrm{mM} \mathrm{PhMeSO}{ }_{2} \mathrm{~F}$ and $15 \mathrm{mM}$ 2-mercaptoethanol, $\mathrm{pH} 7.5$ (buffer A). The homogenate was centrifuged at $40000 \times g$ for $45 \mathrm{~min}$ and the supernatant solution filtered through glass wool. 


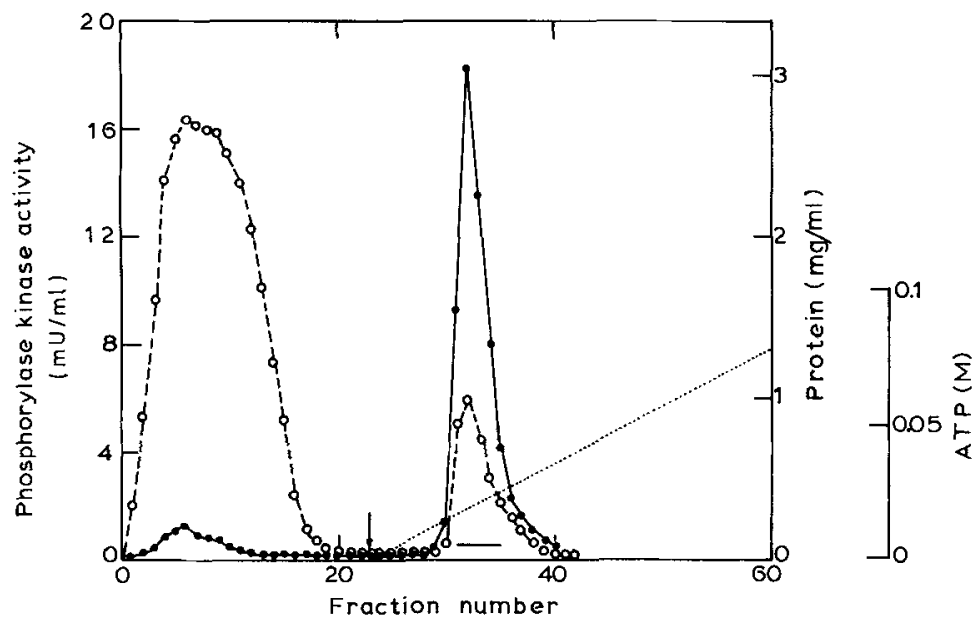

Fig. 1. Elution profile of gizzard phosphorylase kinase from $5^{\prime} A M P$-Sepharose 4 B. Fractions of $10 \mathrm{ml}$ were collected and analyzed for protein $(O--O)$ and phosphorylase kinase activity ( -1$)$, as described in Materials and Methods. The kinase activity was assayed by phosphorylase activation in presence of $20 \mathrm{mM} \mathrm{NaF}$. At the arrow, a $2 \times 250 \mathrm{ml}$ linear gradient of ATP (from 0 to $0.1 \mathrm{M}$ ATP) in buffer A, was applied. Fractions $31-35$ were pooled and concentrated

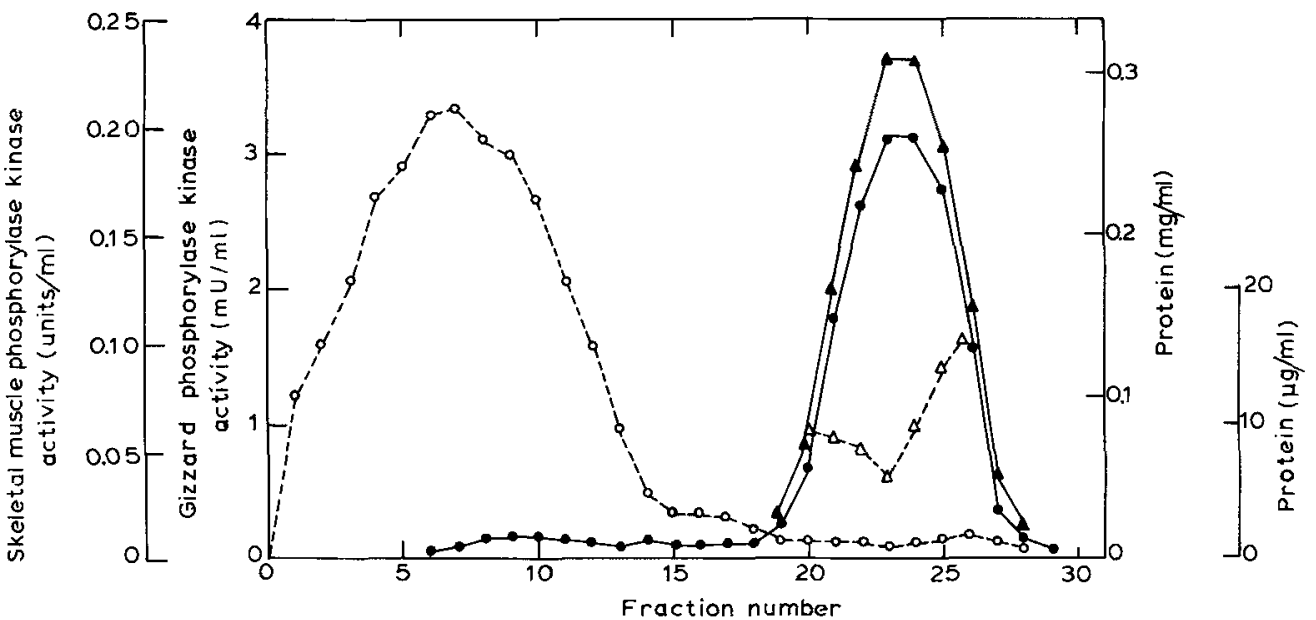

Fig. 2. Glycerol density gradient ultracentrifugation profile of chicken gizzard phosphorylase kinase. Gizzard phosphorylase kinase (2.5 mg) obtained following 5'AMP-Sepharose $4 \mathrm{~B}$ chromatography, was applied to a 36-ml glycerol density gradient $(5-30 \%, \mathrm{w} / \mathrm{v})$ in buffer $\mathrm{A}$. Centrifugation (Beckman SW 28 rotor) was for $22 \mathrm{~h}$ at $95000 \times \mathrm{g}$. Fractions of $1.3 \mathrm{ml}$ were collected, from top to bottom, and assayed for gizzard kinase activity $(-\infty)$ ) and protein $(\bigcirc--O, \mathrm{mg} / \mathrm{ml} ; \wedge--\wedge, \mu \mathrm{g} / \mathrm{ml})$, as described in Materials and Methods. Fractions $21-26$ were pooled and concentrated. ( when centrifuged as described for gizzard kinase

The solution was brought to $40 \%$ saturation in ammonium sulfate by addition of neutralized saturated ammonium sulfate and the precipitated proteins were directly collected by centrifugation for $15 \mathrm{~min}$ at $15000 \times \mathrm{g}$. The pellet was resuspended in buffer $\mathrm{A}$ dialyzed against the same buffer and clarified by centrifugation.

The clear supernatant was applied to a $5^{\prime}$ AMP-Sepharose $4 \mathrm{~B}$ column $(2 \times 38 \mathrm{~cm})$ equilibrated with buffer $\mathrm{A}$. The column was washed with the equilibrating buffer until the protein concentration decreased to zero (Fig.1). The column was then eluted with a linear ATP gradient from $0-0.1 \mathrm{M}$ ATP in buffer A. As much as $10-15 \%$ of the phosphorylase kinase activity applied was not retained by the column. The peak of enzyme activity was pooled as indicated in Fig. 1, concentrated by vacuum dialysis and dialysed against buffer A.

The concentrated enzyme was further purified by glycerol density gradient ultracentrifugation (Fig.2). This procedure takes advantage of the relatively high $\mathrm{Mr}$ of phosphorylase kinase. Fractions containing phosphorylase kinase activity were pooled and concentrated 2-3-fold using flake poly(ethyleneglycol). The protein was stored in $40 \%(\mathrm{v} / \mathrm{v})$ glycerol at $-20^{\circ} \mathrm{C}$. Activity was stable at least two months under these conditions. The above preparation was not homogeneous as judged by SDS-acrylamide gel electrophoresis $(5 \%$ or $7.5 \%$ acrylamide), which revealed the presence of two major protein bands corresponding to $61 \mathrm{kDa}$ and $77 \mathrm{kDa}$, and several other minor bands in the range of $150-100 \mathrm{kDa}$ (not shown). No protein stain was seen at the position of the $\gamma$ or $\delta$ subunit.

To purify gizzard phosphorylase kinase extensively the enzyme obtained from glycerol density gradient ultracentrifugation was applied to a calmodulin-Sepharose $4 \mathrm{~B}$ column. As shown in Fig. 3 all the kinase activity was retained by the column, while about $80 \%$ of the applied protein was not retained. When the column was eluted with the equilibration buffer containing $2 \mathrm{mM}$ EGTA and $0.2 \mathrm{M} \mathrm{NaCl}$, a first kinase activity peak was obtained. Further elution of the column with equilibration buffer containing $2 \mathrm{mM}$ EGTA and $0.5 \mathrm{M}$ 
Table 1. Partial purification of chicken gizzard phosphorylase kinase

$104 \mathrm{~g}$ of chicken gizzard was used for this purification, and phosphorylase kinase activity was assayed by phosphorylase activation in presence of $20 \mathrm{mM} \mathrm{NaF}$, as described in Materials and Methods. The activity at step 3 was determined on the pooled fractions after concentration (3.5-fold) by vacuum dialysis. The activity at step 4 was directly determined on the pooled fractions before concentration. Values in parentheses correspond to the fraction 23 which had the highest specific activity (Fig. 2)

\begin{tabular}{|c|c|c|c|c|c|c|}
\hline Step & Volume & Protein & Activity & Specific activity & Purification & Yield \\
\hline \multirow{5}{*}{$\begin{array}{l}\text { 1. Extract } \\
\text { 2. } 40 \%\left(\mathrm{NH}_{4}\right)_{2} \mathrm{SO}_{4} \text { precipitate } \\
\text { 3. } 5 \text { AMP-Sepharose } 4 \mathrm{~B} \\
\text { 4. Glycerol density gradient } \\
\text { centrifugation }\end{array}$} & $\mathrm{ml}$ & $\mathrm{mg}$ & $\mathbf{U}$ & $\mathrm{U} / \mathrm{mg}$ & -fold & $\%$ \\
\hline & 210 & 2268 & 1.20 & 0.00054 & 1 & 100 \\
\hline & 50 & 36 & 0.55 & 0.015 & 28 & 45 \\
\hline & & & & & & \\
\hline & 93 & 0.9 & 0.26 & 0.29 & 537 & 21 \\
\hline
\end{tabular}

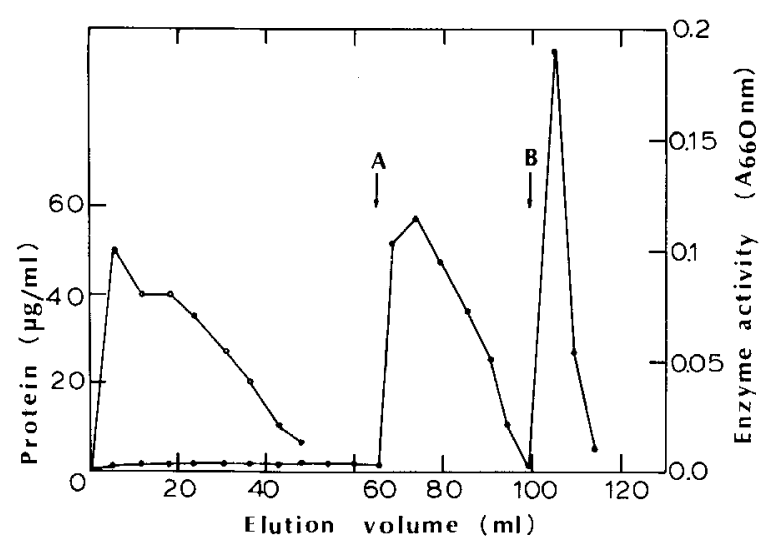

Fig. 3. Chromatography of gizzard phosphorylase kinase on calmodulinSepharose 4 B. Gizzard phosphorylase kinase $(0.3 \mathrm{mg})$ obtained from glycerol density gradient ultracentrifugation was applied to a calmodulin-Sepharose $4 \mathrm{~B}$ column $(3 \mathrm{ml})$ equilibrated in $50 \mathrm{mM}$ Tris/ $\mathrm{HCl}$ buffer $\mathrm{pH} 7.0$ containing $5 \mathrm{mM} \mathrm{MgCl} 2,1 \mathrm{mM}$ EDTA, $10 \mathrm{mM}$ 2-mercaptoethanol and $2 \mathrm{mM} \mathrm{CaCl}$. The enzyme was previously dialysed against the same buffer. The column was washed with the above buffer until no protein could be detected in the eluate. At arrows $A$ and $B$ the column was washed with the equilibration buffer containing $2 \mathrm{mM}$ EGTA, $0.2 \mathrm{M} \mathrm{NaCl}$ and $2 \mathrm{mM}$ EGTA, $0.5 \mathrm{M} \mathrm{NaCl}$ respectively. The low protein concentration of the fractions obtained after $50 \mathrm{ml}$ elution volume prevented protein determination. ( $\bigcirc)$ Protein concentration; $(\bullet)$ phosphorylase kinase activity at $\mathrm{pH} 8.6$ as determined by measuring phosphorylase $a$ activity $\left(A_{660}\right)$

$\mathrm{NaCl}$ gave a second phosphorylase kinase activity peak. The two kinase activity peaks, which possibly represent different types of interaction between the gel matrix and the kinase molecule, were pooled together, concentrated by vacuum dialysis and analyzed by SDS-acrylamide gel electrophoresis. As shown in Fig. 4, SDS gel electrophoresis in $7.5 \%$ acrylamide resolved one major protein band corresponding to $61 \mathrm{kDa}$ and four minor bands corresponding to $137,126,113$ and $77 \mathrm{kDa}$. Again, no protein stain was seen at the position of $\gamma$ subunit. The presence of a strong protein-staining band at the position of $\delta$ subunit is possibly due to calmodulin desorbed from the calmodulin-Sepharose column during the chromatographic process, because in the previous purification step calmodulin was not detected.

Table 1 shows a summary of the scheme for partial purification of chicken gizzard phosphorylase kinase. The final purification step of calmodulin-Sepharose 4 B affinity chromatography was not included in Table 1 , because the low protein concentrations of the phosphorylase kinase fractions prevented protein determination, and the effect of hight salt concentrations on the gizzard kinase activity is not known.

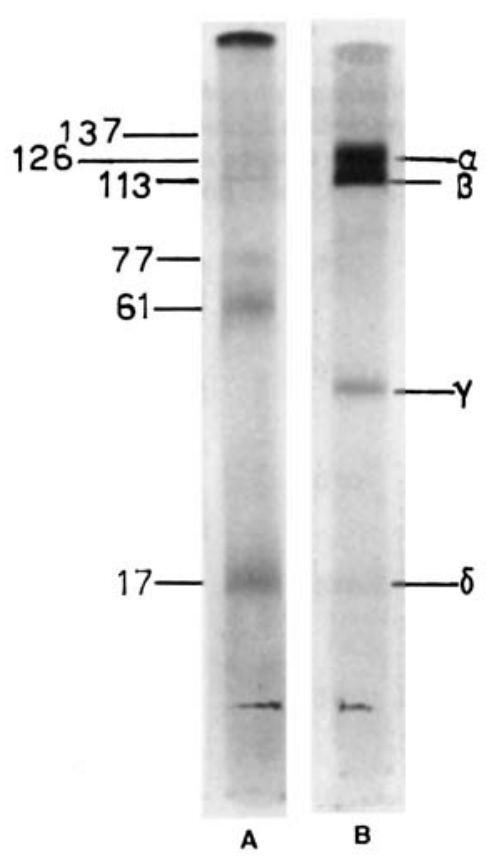

Fig. 4. SDS-polyacrylamide gel electrophoresis of chicken gizzard phosphorylase kinase after calmodulin-Sepharose $4 B$ affinity chromatography. The tube gels contained $7.5 \%$ polyacrylamide. $15 \mu \mathrm{g}$ of gizzard phosphorylase kinase (A) and $26 \mu \mathrm{g}$ of skeletal muscle phosphorylase kinase (B) were applied to the gels. Other conditions were as described in Materials and Methods. Values on the left are molecular masses in $\mathrm{kDa}$

\section{Molecular mass and substrate specificity}

The molecular mass of chicken gizzard phosphorylase kinase was found to be similar to that of rabbit skeletal muscle enzyme by glycerol density gradient ultracentrifugation (Fig.2), although the subunit patterns of the two kinases seems to be different (Fig.4).

The purified chicken gizzard phosphorylase kinase did not appreciably incorporate ${ }^{32} \mathrm{P}_{\mathrm{i}}$ from $\left[\gamma-{ }^{32} \mathrm{P}\right] \mathrm{ATP}$ donor into histone II-AS, casein, phosvitin and whole troponin (less than $1 \%$ activity when compared to the activity presented with rabbit muscle phosphorylase $b$ at $\mathrm{pH} 8.6$ ).

\section{Kinetic properties}

Fig. 5 illustrates the effect of $\mathrm{pH}$ on conversion from phosphorylase $b$ to $a$ by chicken gizzard phosphorylase kinase. The enzyme displays little activity near $\mathrm{pH} 6.0$, while 


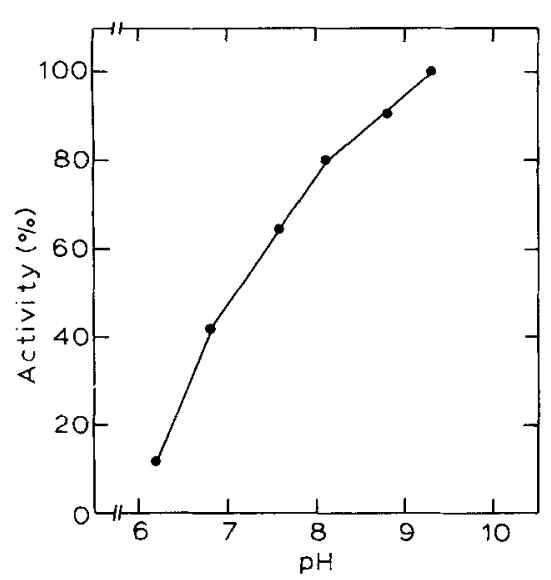

Fig. 5. pH profile of chicken gizzard phosphorylase kinase. Phosphorylase kinase activity was assayed at the $\mathrm{pH}$ values indicated by phosphorylase activation, as described in Materials and Methods, except that $50 \mathrm{mM}$ Tris-maleate buffer was used. The activity at $\mathrm{pH} 9.3$ was taken as $100 \%$

the activity increases progressively from $\mathrm{pH} 6.2$ to 9.3 . The $\mathrm{pH} 6.8 / 8.2$ activity ratio obtained with different preparations was always high $(0.58 \pm 0.05$, mean \pm SD for four preparations), similar to the $\mathrm{pH}$ activity ratio of the phosphorylated form of rabbit skeletal muscle phosphorylase kinase [20].

Fig. $6 \mathrm{~A}$ shows the activity of gizzard phosphorylase kinase at various phosphorylase $b$ concentrations in the presence of $3 \mathrm{mM}$ ATP and $10 \mathrm{mM} \mathrm{Mg}^{2+}$. The activity originally increased and then decreased as the concentration of the protein substrate in the system was raised. The maximal activity was obtained with about $0.5 \mathrm{mg} / \mathrm{ml}$ of phosphorylase $b$, while at $10 \mathrm{mg} / \mathrm{ml}$ of the protein substrate a fivefold lower activity was observed.

Fig. 6 B shows the activity of gizzard phosphorylase kinase as a function of ATP concentration when the molar ratio $\mathrm{Mg}^{2+} /$ ATP was constant at a value of 3.3. Maximal phosphorylase kinase activity was observed at $2 \mathrm{mM}$ ATP, while higher concentrations of the nucleotide are inhibitory. The $K_{\mathrm{m}}$ value for ATP was found $0.45 \pm 0.05 \mathrm{mM}$ (mean $\pm \mathrm{SD}$ for four determinations).

\section{Phosphorylation and activation state}

An attempt was made elucidate the phosphorylation and activation state of the gizzard kinase preparations by four independent methods. (a) The enzyme was prepared using the standard purification procedure cited above, but including in $50 \mathrm{mM} \mathrm{NaF}$ all purification steps, in order to block the action of protein phosphatases [21]. In this case, the $\mathrm{pH} 6.8 / 8.2$ activity ratio obtained with four different preparations was found $0.53 \pm 0.05$ (mean $\pm \mathrm{SD}$ ), which is practically the same with that obtained in absence of NaF. (b) Gizzard phosphorylase kinase prepared in absence of $\mathrm{NaF}$ was preincubated with phosphorylase phosphatase and then tested for possible inactivation of the kinase at $\mathrm{pH} 6.8$. No evidence was obtained indicating that the gizzard kinase was already in an activated phosphorylated form. (c) The activity of the purified preparations of gizzard phosphorylase kinase at pH 6.8 was not affected by the catalytic subunit of cyclicAMP-dependent protein kinase. Incubation of the gizzard enzyme with ATP-Mg and a large excess of the catalytic subunit, up to $15 \mathrm{~min}$, had no effect on the rate of conversion of phosphorylase $b$ to $a$. (d) No autophosphorylation of gizzard
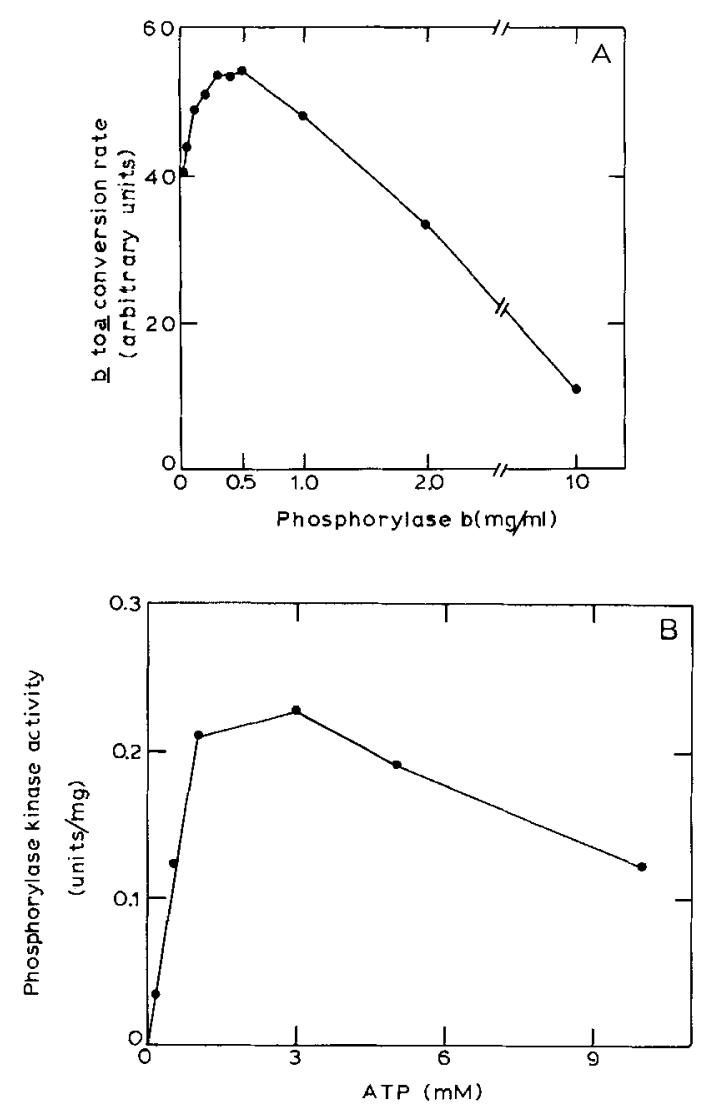

Fig. 6. Effect of phosphorylase $\mathrm{b}(A)$ and ATP $(B)$ concentration on the activity of chicken gizzard phosphorylase kinase. (A) Phosphorylase kinase activity was assayed by phosphorylase activation, at $\mathrm{pH} 8.6$. as described in Materials and Methods, except that the concentration of phosphorylase $b$ was varied from $40 \mu \mathrm{g} / \mathrm{ml}$ to $10 \mathrm{mg} / \mathrm{ml}$ and the gizzard kinase was present at $1 \mu \mathrm{g} / \mathrm{ml} . b$ to $a$ conversion rate is expressed in arbitrary units. (B) Phosphorylase kinase activity was assayed as in $\mathrm{A}$, except that the concentration of phosphorylase $b$ was constant $(0.5 \mathrm{mg} / \mathrm{ml})$, while the ATP concentration was varied from $0.2 \mathrm{mM}$ to $10 \mathrm{mM}$ and the ratio $\mathrm{Mg}^{2+} / \mathrm{ATP}$ was kept constant at 3.3

phosphorylase kinase was observed over a 120 min reaction time, while under the same experimental conditions skeletal muscle phosphorylase kinase incorporated ${ }^{32} \mathrm{P}_{\mathrm{i}}$ into $\alpha$ and $\beta$ subunits.

\section{Effect of $\mathrm{Ca}^{2+}$ and calmodulin}

Gizzard phosphorylase kinase is stimulated by low concentrations of free $\mathrm{Ca}^{2+}$ (Fig. 7). At approximately $4 \mu \mathrm{M}$ of free $\mathrm{Ca}^{2+}, 20 \%$ of the original activity was obtained. Further decrease of free $\mathrm{Ca}^{2+}$ up to $3 \mathrm{nM}$ did not change phosphorylase kinase activity. The concentration of free $\mathrm{Ca}^{2+}$ necessary for obtaining half-maximum activity was calculated to be about $25 \mu \mathrm{M}$. This value is in the same order of magnitude as that obtained for $\mathrm{A}_{2}$ activity of muscle phosphorylase kinase [22].

Calmodulin was found to increase the activity of gizzard phosphorylase kinase when it was included in the standard assay. Fig. 8 shows the activity of the kinase as a function of added calmodulin concentration, at $\mathrm{pH} 6.8$. The maximal stimulation was 1.9 -fold over the basal activity. The concentration of calmodulin required for half-maximal enzyme activation was about $0.7 \mu \mathrm{M}$, while the maximal activity was obtained at about $1.3 \mu \mathrm{M}$. At $\mathrm{pH} 8.6$, maximal stimulation 


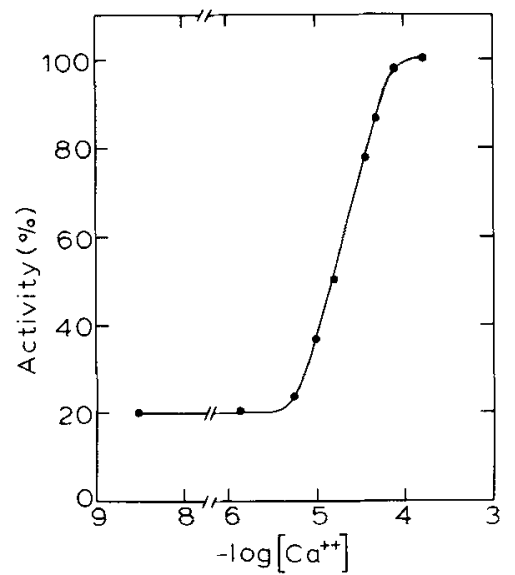

Fig. 7. Activation of gizzard phosphorylase kinase by $\mathrm{Ca}^{2+}$. Phosphorylase kinase $(0.33 \mu \mathrm{g} / \mathrm{ml})$ was assayed at $\mathrm{pH} 8.6$ in a reaction mixture containing $50 \mathrm{mM}$ Tris $/ \mathrm{HCl}, 2.5 \mathrm{mM}$ glycerol 2-phosphate, $20 \mathrm{mM} \mathrm{NaF}, 0.5 \mathrm{mg} / \mathrm{ml}$ phosphorylase $b, 0.073 \mathrm{mM}$ EDTA, $2 \mathrm{mM}$ 2-mercaptoethanol, $3 \mathrm{mM}$ ATP, $10 \mathrm{mM}$ magnesium acetate, $2.5 \%$ (v/v) glycerol, $0.2 \mathrm{mM} \mathrm{CaCl}_{2}$ and various amounts of EGTA to provide the desired concentration of free $\mathrm{Ca}^{2+}$ as indicated. The concentration of free $\mathrm{Ca}^{2+}$ was calculated by using a Fortran program, kindly supplied by Professor L. M. G. Heilmeyer Jr and the logarithmic association constants employed by Kiliman and Heilmeyer [22]

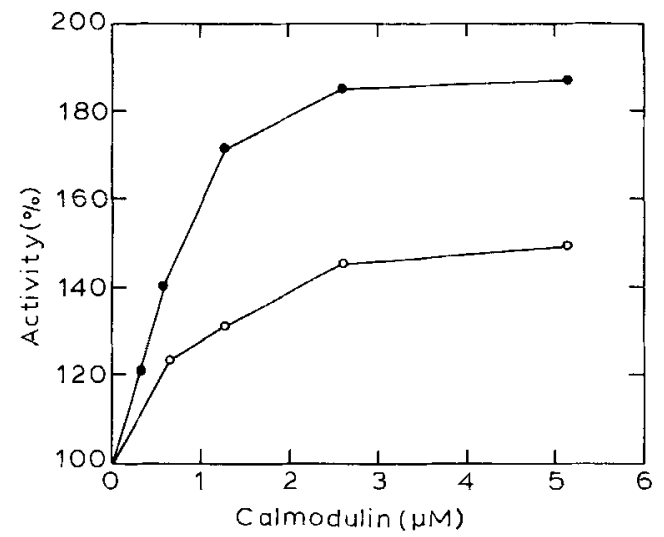

Fig. 8. Activation of chicken gizzard phosphorylase kinase by exogenous calmodulin. Phosphorylase kinase activity was determined at $\mathrm{pH} 6.8$ (-) or $8.6(0)$, by measuring the incorporation of ${ }^{32} \mathrm{P}$ from $\left[\gamma^{-}{ }^{32} \mathrm{P}\right]-$ ATP into phosphorylase $b$, as described in Materials and Methods. The gizzard kinase was present at $1 \mu \mathrm{g} / \mathrm{ml}$. Activity of phosphorylase kinase in the absence of calmodulin is taken as $100 \%$

was obtained at the same concentration of calmodulin but the stimulation value was lower (1.5-fold).

\section{Activation of gizzard phosphorylase kinase by trypsin}

It is well known that the action of trypsin leads to an activation of rabbit skeletal muscle phosphorylase kinase [11]. When gizzard phosphorylase kinase was incubated with trypsin, the enzyme activity at $\mathrm{pH} 6.8$ was raised twofold within $3 \mathrm{~min}$, while further incubation resulted in a decrease of kinase activation (Fig.9). Under the same experimental conditions, rabbit skeletal muscle phosphorylase kinase was activated 47-fold within $6 \mathrm{~min}$ and no further change of enzyme activity was observed up to 20 min incubation (Fig. 9).

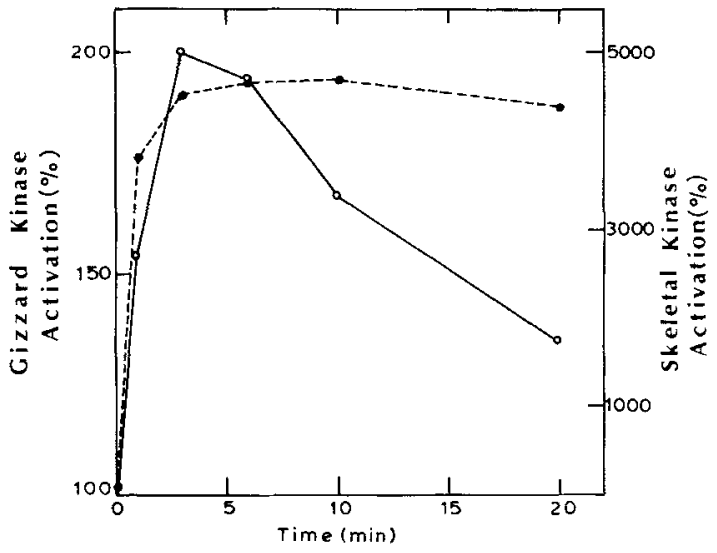

Fig. 9. Time course of proteolytic activation of gizzard $(\mathrm{O}-\mathrm{O}$ and skeletal muscle (-_- - ) phosphorylase kinase by trypsin. Enzyme activity at zero time was taken as $100 \%$. Other conditions were as described in Materials and Methods

\section{DISCUSSION}

To date most knowledge of phosphorylase kinase at the molecular level has been derived from studies with the enzymes from rabbit skeletal muscle [2, 14], bovine cardiac muscle [23-25], dogfish skeletal muscle [26] and liver [18, 27-29]. In this respect the rabbit skeletal muscle enzyme has been the most thoroughly characterized in terms of its physicochemical, enzymatic and more importantly regulatory properties. In the present study we present information on the extensive purification and characterization of phosphorylase kinase isolated from the smooth muscle of chicken gizzard. The purification (about 1000-fold) necessary to obtain the partially pure preparation of gizzard phosphorylase kinase is about 10-fold higher than the $100-150$-fold purification required to obtain the homogeneous rabbit skeletal muscle enzyme [11,30]. Assuming that the turnover numbers of the two kinases are not significantly different, this suggests a relatively much lower concentration of phosphorylase kinase in chicken gizzard.

The initial findings of glycerol density gradient centrifugation (Fig. 2) suggest that gizzard phosphorylase kinase resembles the skeletal muscle enzyme as to molecular mass. In this respect it was very puzzling that the purified preparation of gizzard kinase presented a major protein component of $61 \mathrm{kDa}$ on SDS-acrylamide gel electrophoresis, while no protein stain was seen at the position of the $\gamma$ subunit (Fig. 4). A possible explanation for the appearance of the major protein band at $61 \mathrm{kDa}$ and the minor components with similar mobilities to those of $\alpha$ and $\beta$ subunits of rabbit skeletal muscle phosphorylase kinase, could be a proteolytic cleavage of the smooth muscle kinase molecule. This possibility is in accordance with the fact that the activity ratio $\mathrm{pH} 6.8 / 8.2$ of smooth muscle enzyme is close to that observed for trypsin activated skeletal muscle phosphorylase kinase $[2,11]$. However, the experimental results presented in this paper argue against such an explanation. First, gizzard phosphorylase kinase showed a single peak of kinase activity during glycerol density gradient ultracentrifugation (Fig.2). Under similar sucrose gradient centrifugation conditions, trypsin-activated skeletal muscle phosphorylase kinase dissociated to several catalytically active enzyme forms [31]. Second, proteolysis of the gizzard kinase enhanced the enzyme activity twofold at pH 6.8 (Fig.9). Third, gizzard phosphorylase kinase was 
activated by calmodulin (Fig. 8) and was bound quantitatively to a calmodulin affinity column (Fig. 3). On the other hand proteolytically degraded rabbit skeletal muscle phosphorylase kinase is neither stimulated by calmodulin nor can bind to a calmodulin affinity column [32]. Fourth, $\gamma$ subunit, which is known to be resistant to proteolysis $[2,11]$, has not been detected. One cannot exclude the possibility that the inability to detect polypeptides with molecular mass similar to that of $\gamma$ subunit (Fig. 4) or $\delta$ subunit (glycerol density ultracentrifugation step) may be due to the low amount of protein put on the gels $[26,27]$

Gizzard phosphorylase kinase showed an extremely high affinity for phosphorylase $b$ and a biphasic dependence on protein substrate concentration. Thus, the concentration of rabbit muscle phosphorylase $b$ needed for half-maximal activity was more than 200-fold and 85-fold lower than the $K_{\mathrm{m}}$ of non-activated $(40 \mu \mathrm{M})$ or activated $(17 \mu \mathrm{M})$ rabbit muscle phosphorylase kinase respectively, for the protein substrate [30]. In this respect, dogfish skeletal muscle [26] bovine heart [25] and rat liver phosphorylase kinase [27] are also known to exhibit very large $K_{\mathrm{m}}$ values for phosphorylase $b$. In contrast, Sakai et al. [28] reported low $K_{\mathrm{m}}$ values for the protein substrates (muscle and liver phosphorylase $b$ ) of rabbit liver phosphorylase kinase. As far as the biphasic effect of phosphorylase $b$ concentration on the activity of smooth muscle phosphorylase kinase is concerned, this may be due to the existence of more than one type of binding sites for the protein substrate.

It has been reported previously that $\mathrm{Ca}^{2+}$, a stimulant of skeletal muscle phosphorylase kinase, also plays an important role in the regulation of phosphorylase activity of arterial smooth muscle [6]. The experimental results presented in this paper concerning the stimulation of purified gizzard phosphorylase kinase by free $\mathrm{Ca}^{2+}$ (Fig.7) and its activation by exogenous added calmodulin (Fig. 8), suggest that like skeletal muscle [3] and liver [18, 28, 33] phosphorylase kinase, gizzard phosphorylase kinase is also $\mathrm{Ca}^{2+}$-calmodulin regulated.

The data presented herein serve to indicate that gizzard phosphorylase kinase can neither be autophosphorylated nor activated by phosphorylation with protein kinase, thus showing similarities with dogfish skeletal muscle phosphorylase kinase [26]. In this respect, Namm [6] has shown that cyclic AMP in concentrations up to $100 \mu \mathrm{M}$ was without effect on the phosphorylase activation of arterial smooth muscle. This observation is in accordance with our data concerning the phosphorylation state of gizzard phosphorylase kinase. The possibility remains that the concentration of the gizzard enzyme used as substrate in the phosphorylation-dephosphorylation reactions was insufficient, or that the gizzard kinase may be desensitized for activation during the purification procedure.

During the preparation of this paper Tsutou et al. [34] published a short communication on a partial purification of porcine uterine smooth muscle phosphorylase kinase. They also reached the conclusion that the smooth muscle kinase was activated about $1.5-2.0$-fold by exogenous calmodulin and that $\mathrm{Ca}^{2+}$ activation of the enzyme was greatly inhibited by EGTA.

We are greatly indebted to Dr A. E. Evangelopoulos and Dr N. G. Oikonomakos for invaluable discussions throughout the course of this work. We thank Prof. L. M. G. Heilmeyer, Jr for his generous gifts of the catalytic subunit of bovine heart cyclic-AMP-dependent protein kinase, bovine brain calmodulin and whole troponin. We gratefully acknowledge the assistance of Miss A. E. Melpidou in the purification of rabbit muscle phosphorylase, phosphorylase kinase and phosphorylase phosphatase. We are also grateful to Dr Kornelia Jaquet for computation of the $\mathrm{Ca}^{2+}$ concentrations.

\section{REFERENCES}

1. Cohen, P., Burchell, A., Foulkes, J. G., Cohen, P. T. W., Vanaman, T. C. \& Nairn, A. C. (1978) FEBS Lett. 92, 287293.

2. Carlson, G. M., Bechtel, P. J. \& Graves, D. J. (1979) $A d v$ Enzymol. 50, $41-115$.

3. Cohen, P. (1980) Eur. J. Biochem. 111, 563-574.

4. Hartshorne, D. J. \& Siemankowski, R. F. (1981) Annu. Rev. Physiol. 43, 519-530.

5. Adelstein, R. S. (1983) J. Clin. Invest. 72, 1863-1866.

6. Namm, D. H. (1971) J. Pharmacol. Exp. Ther. 178, 299-310.

7. Diamond, J. \& Janis, R. A. (1980) Br. J. Pharmacol. 68, $275-$ 282.

8. Silver, P. J. \& Stull, J. T. (1982) J. Biol. Chem. 257,6145-6150.

9. Sotiroudis, T. G., Cazianis, C. T., Oikonomakos, N. G. \& Evangelopoulos, A. E. (1983) Eur. J. Biochem. 131, 625-631.

10. Fischer, E. H. \& Krebs, E. G. (1962) Methods Enzymol. 5, $369-$ 373.

11. Cohen, P. (1973) Eur. J. Biochem. 34, 1-14.

12. Gopalakrishna, R.\& Anderson, W. B. (1982) Biochem. Biophys. Res. Commun. 104, 830-836.

13. Antoniw, F. \& Cohen, P. (1976) Eur. J. Biochem. 68, 45-54.

14. Cohen, P. (1983) Methods Enzymol. 99, 243-250.

15. Bradford, M. M. (1976) Anal. Biochem. 72, 248-254.

16. Kastenschmidt, L. L., Kastenschmidt, J. \& Helmreich, E. (1968) Biochemistry 7, 3590-3608.

17. Szücs, K., Vereb, G. \& Bot, G. (1983) Int. J. Biochem. 15, $1161-$ 1167.

18. Chrisman, T. D., Jordan, J. E. \& Exton, J. H. (1982) J. Biol. Chem. 257, 10798-10804.

19. Niggli, V., Penniston, J. T. \& Carafoli, E. (1979) I. Biol. Chem. 254, $9955-9958$.

20. Krebs, E. G., De Lange, R. J., Kemp, R. G. \& Riley, W. D. (1966) Pharmacol. Rev. 18,163-171.

21. Revel, H. R. (1963) Methods Enzymol. 6, 211-214.

22. Kilimann, M. W. \& Heilmeyer, L. M. G., Jr (1982) Biochemistry $2 l, 1727-1734$.

23. Cooper, R. H., Sul, H. S., McCullough, E. \& Walsh, D. A. (1980) J. Biol. Chem. 255, 11794-11801.

24. Sul, H. S., Cooper, R. H., Whitehouse, S. \& Walsh, D. A. (1982) J. Biol. Chem. 257, 3484-3490.

25. Killilea, S. D. \& Ky, N. M. (1983) Arch. Biochem. Biophys. 221, $333-342$

26. Pocinwong, S., Blum, H., Malencik, D. \& Fischer, E. H. (1981) Biochemistry, 20, 7219-7226.

27. Vandenheede, J. R., De Wull, H. \& Merlevede, W. (1979) Eur. J. Biochem. 101, 51-58.

28. Sakai, K., Matsimura, S., Okimura, Y., Yamamura, H. \& Nishizuka, Y. (1979) J. Biol. Chem. 254, 6631-6637.

29. Doorneweerd, D. D., Tan, A. W. H. \& Nuttall, F. Q. (1982) Mol. Cell. Biochem. 47, 45-53.

30. Krebs, E. G., Love, D. S., Bratfold, G. E., Trayser, K. A., Meyer W. L. \& Fischer, E. H. (1964) Biochemistry, 3, 1022-1033.

31. Graves, D. J., Hayakawa, T., Horvitz, R. A., Beckman, E. \& Krebs, E. G. (1973) Biochemistry, 12, 580-585.

32. DePaoli-Roach, A. A., Gibbs, J. B. \& Roach, P. J. (1979) FEBS Leti. 105, $321-324$.

33. Nakamura, S., Tsutou, A., Mizuta, K., Negami, A., Nakaza, T., Hashimoto, E. \& Yamamura, H. (1983) FEBS Lett. 159 $47-50$.

34. Tsutou, A., Nakamura, S., Negami, A., Mizuta, K., Hashimoto, E. \& Yamamura, H. (1985) Biochem. Biophys. Res. Commun. $126,544-550$ 